\title{
ЕКСПЕРИМЕНТАЛЬНЕ ВИВЧЕННЯ ЕКЗИСТЕНЦІЙНИХ ДАНОСТЕЙ БУТТЯ ОСОБИСТОСТІ
}

УдК: 159.9.072.432

\section{Панфілов Дмитро Анатолійович}

\begin{abstract}
Аспірант лабораторії психології спілкування, Iнститут сочіальної та політичної психології Національної академії педагогічних наук Украӥни, м. Київ (Україна)
\end{abstract}

\begin{abstract}
Анотація. $\quad$ У статті представлені результати експериментального дослідження екзистенційних даностей буття особистості. Отримані дані дали змогу визначити три фактори, щзо характеризують екзистенџійну ситуаџію особистості. Фактор «усвідомлення самості» є змістовою характеристикою, яка розкриває особистісні, сутнісні особливості, що визначають прийняття себе особистістю. «Життєва самоперетворювальність» - ией фактор визначає результативні та регулятивні якості особистості: «мету в житті», «загальний показник осмисленості життя», «процес життя», «результативність життя», «локус контролю-я», «локус контролю-життя». "Самоактивація життєстійкості» - розкриває такі сутнісні якості особистості: життєстійкість, контроль, залучення, прийняття ризику, тривога. Наведені фактори в ичілому визначають екзистениійну ситуацію особистості і дають змогу розробити ефективну стратегію практичної роботи з клієнтом. Створення моделі конструктивного, осмисленого життя людини - багатомірний процес.
\end{abstract}

Ключові слова: екзистениійні даності буття, особистість, екзистенція, життєстійкість, самість.

Постановка проблеми. У сучасній психології фундаментальні даності буття особистості вивчаються у межах їі екзистенційного напрямку. Такий підхід дає змогу досліджувати глибинні процеси, які значною мірою обумовлюють мотивацію, поведінку, емоції людини. Представники екзистенційної парадигми розкривають екзистенційні даності, зокрема такі їх особливості, що є фундаменталь- ними 3 точку зору психодинаміки. Будь-яка даність людського існування - смерть, ізоляція, свободачи абсурдність буття- обумовлюють виявлення у людини так званої екзистенційної тривоги, спричиняютьвиникнення внутрішніх особистісних конфліктів i, унаслідок свого всеохоплюючого характеру, впливають на різноманітнісфери життя особистості. Крім того, інформативними для вивчення особливо- 
стей поведінки людини у соціальному середовищі стають такі захисні механізми, що формуються у разі недостатнього усвідомлення даностей буття. Продуктивне розв 'язання внутрішньо-особистісних і соціальних конфліктів, прийняття людиною найважливіших аспектів власного існування $\epsilon$, водночас, і психотерапевтичною задачею, і фактором розвитку людини, яка створює сенс власного буття. Визначення чинників, що сприяють або заважають становленню продуктивного сенсу життя особистості, допоможе коригувати цей процес. Вивчення екзистенційних даностей дає змогу, краще зрозуміти мотивацію клієнта та віднаходити i застосовувати у професійній діяльності більш ефективні психотерапевтичні підходи для практичної допомоги людині в кризових ситуаціях, при особистісних психологічних розладах, депресивних станах тощо.

\section{Аналіз досліджень і публікацій.}

Кожна екзистенційна даність буття супроводжується переживанням особистістю екзистенційної тривоги. Конфронтація з цими даностями обумовлює так званий екзистенційний конфлікт. І. Ялом визначає три екзистенційні конфлікти особистості: між потребою жити і невідворотністю смерті, між екзистенційною ізоляцією і прагненням симбіозу, між свободою і необхідністю [4].

До того ж екзистенціальна традиція розглядає «відвагу бути» як смисловий, світоглядний феномен. Серед передумов виникнення цього феномену С. Мадді відзначає віру в себе, впевненість у власній цінності і здатності жити, а також такі когнітивні функції, що створюють сенс: символізація, уява, судження. Систему установок, контроль над ними, а також відкритість викликам і ризику С. Мадді називає життєстійкістю [6].

Тим часом П. Тіліх вказує на наявність у людини особливого типу відваги - екзистенційний іiі різновид [10]. Внутрішня тривога, за П. Тіліхом, проявляє себе, як страх людини щодо своєї долі і власної смерті, провини і засудження, внутрішньої порожнечі і втрати сенсу. Мужність - це самоствердження особистості всупереч цим загрозам, що сприймаються як різні види ії̈ небуття.

У цьому контексті тривога смерті розглядається також В. Ю. Баскаковим. Автор і розробник танатотерапії аналізує феномен смерті та особливості його сприйняття людиною. Танатотерапія ставить за мету допомогти людині подолати ірраціональний страх смерті і відчути «нормальність» iï боязні, яка, на думку В. Ю. Баскакова, є прагненням до жит[11].

Дослідження, дотичні до розкриття проблеми екзистенційного страху смерті, проводились Е. Кюблер-Росс [8]. Дослідниця вивчала реакції смертельно хворих людей на власну екзистенційну ситуацію. Вона схарактеризувала такі етапи прийняття людиною власної смерті: заперечення, гнів, торг, депресія і прийняття, що вказує на динамічний характер взаємодії людини з власною екзистен- 
цією.

Р. Ленг визначає три основні форми тривоги, які «пронизують» повсякденне життя «нещасної свідомості»: «поглинання», «прорив», «скам'яніння», що свідчить про те, що у разі, коли людина не приймає власної тривоги, наслідком цього є специфічні екзистенційні порушення [7]. Р. Ленг розкриває профіль особистості з низьким рівнем тривоги смерті. Для такої особистості характерні ознаки:

- цілеспрямованість, наявність цілей, які надають осмисленості, спрямування та часової перспективи;

- $\quad$ задоволеність своїм життям, сприйняття процесу його проживання як цікавого, емоційно насиченого і наповненого сенcom;

- $\quad$ самореалізація, відчуття продуктивності і осмисленості життя;

- $\quad$ локус контролю - Я.

Зазначимо, що основним вихідним положенням екзистенційної парадигми $є$ розкриття не розривної єдності між суб'єктом та об’єктом. Так, Виборних Д. Е. встановлює вплив даностей буття на соматичні захворювання людини, аналізуючи результати, одержані в ході застосування екзистенційної психотерапії та дослідження ii ефективності на перебіг депресій, зниження тривоги, нормалізації апетиту, сну.

Характеризуючи екзистенційний вакуум, О. О. Лисенкова окреслює когнітивний, емоційний i мотиваційно-діяльнісний його компоненти.

Д. Ю. Снітько виявляє тісний зв'язок між страхом та пасивною поведінкою. Обидва аспекти страху (причетність до людського розуму та вкоріненість в самій екзистенції) не заперечують один одному, а лише презентують різні виміри людського буття - свободу та «відчуженість». Автор вказує на те, що опозиція до страху та до «мужності бути» має онтологічний та екзистенційний виміри, сутнісні діалектичні особливості і співвідноситься із людською діяльністю і бездіяльністю[5].

О. О. Дасаєва, характеризуючи зв'язок між тілом та екзистенцією, розкриває основні риси людської тілесності. На іï думку, тіло людини, по-перше, пов'язане зі своєю власною і чужою, сторонньою тілесністю. Людина усвідомлює це і завдяки тому має змогу осягнути власну ідентичність через породження тілесного модусу життєвого досвіду. Подруге, характеризуючи поняття «дотик», дослідниця виявила зв'язок між тілесністю і навколишнім світом, так звану «точку комунікації» людини зі світом. По-третє, завдяки тілесному досвіду буття людина має змогу сприймати оточуючий світ [5].

Розглядаючи феномен самотності і особливості його виявлення, Ф. О. Василюк стверджує, що онтологічний його статус втілюється в наступних модусах:

самотність має феноменальну природу; самотність є комплексним станом; 
Ti.

Ф. О. Василюк характеризуючи емоції, які переживає людина в екзистенційному просторі, акцентує увагу на тому, що вони відрізняються від емоцій, що виявляються в простоpi соціальному: 1) за способом виникнення; 2) за формою перебігу; 3) за особливостями переживання [5].

Мета статті: полягає у визначеннів ході експериментального дослідження характеристик екзистенційних даностей буття особистості.

Виклад основаного матеріалу дослідження.

Для досягнення поставленої мети у процесі дослідження екзистенційних даностей буття особистості нами використано наступні методики: шкала тривоги Шихана, шкала екзистенції, тест життєстійкості С. Мадді, тест смисложиттєвих орієнтацій (СЖО).

Так, тест смисложиттєвих орієнтацій $є$ адаптованою версією тесту «Мета вжитті» (Purpose-in-LifeTest, PIL) Джеймса Крамбо і Леонарда Махолика [1]. Методика була розроблена авторами на основі теорії прагнення до сенсу і логотерапії Віктора Франкла. Шкала «Мета в житті» визначається авторами як переживання індивідом онтологічної значущості життя.

Застосований у дослідженні тест СЖО містить у своєму складі двадцять пар протилежних тверджень, що відображають уявлен- ня людини про фактори осмислення нею життя. Важливим тут є чітке співвідношення цілей: 3 майбутнім (емоційна насиченість), 3 теперішнім (відчуття задоволення від досягнутих результатів), з минулим (узгодженість 3 попереднім досвідом). Основою такого вибору є сформоване уявлення про сенс життя або його відсутність. Сукупність здійснених, актуалізованих виборів формує «минуле», яке $\epsilon$ незмінним. «Майбутнє» при цьому є сукупністю потенційних, очікуваних результатів зусиль, а різні варіанти очікуваного мають різну мотивуючу привабливість. «Теперішнє» дає змогу вирішувати життєві завдання «тут-ітепер» на основі попереднього досвіду та очікувань від майбутнього.

Використану у нашому дослідженні шкалу екзистенції, розроблено в рамках екзистенційно-аналітичної теорії Альфріда Ленгле [2]. У 1988-1989 рр. Крістін Орглер, сформулювала питання і отримала перші дані щодо їі стандартизації[3]. Методика вимірює екзистенційну наповненість - поняття, що вперше 3'явилося в логотерапії В. Франкла. «Ступінь» або «рівень» екзистенціальної наповненості розкриває міру відповідності рішень і вчинків людини iі цінностям, тобто означена шкала відображає суб'єктивну оцінку людиною свого життя.

У свою чергу тест життєстійкості $є$ адаптацією Д. О. Леонтьєвим опитувальника Hardiness Survey, розробленого американським психологом Сальваторе Мадді [3]. Жит- 
тєстійкість -це така система переконань людини, за допомогою якої вона ефективно долає стресові ситуації. В одній і тій самій ситуації людина 3 високою життєстійкістю краще справляється зі стресом. Життєстійкість складається з трьох компонентів: залучення, контроль, прийняття ризику [3]. Поняття життєстійкості є аналогічним поняттю «мужність бути», введеному П. Тілліхом в рамках екзистенційного підходу. Екзистенціальна відвага передбачає готовність «діяти всупереч» - $\Rightarrow$ всупереч онтологічній тривозі, страху втратити сенс життя, а також намагання протистояти відчуттю «занедбаності» (М. Гайдеггер). Саме життєстійкість дає змогу людині витримувати екзистенційну тривогу, яка зумовлює вибір майбутнього (невідомого) всупереч минулому (незмінного) в ситуації екзистенційної дилеми.

Шкалу самооцінки тривоги Шихана (Sheehan Patient-Rated Anxiety Scale, SPRAS), що використовується у діагностиці тривожних розладів, зокрема, з метою вимірювання рівня клінічно значущої тривоги, розроблено автором у 1983 році [1]. Високі показники рівня тривоги за цією шкалою вказують на наявність у людини того чи іншого тривожного $\Rightarrow$ розладу.

Окрім того обрані нами методики да- $\Rightarrow$ ють змогу дослідити:

$\Rightarrow$ екзистенційність - здатність людини орієнтуватися в світі, самостійно вирішувати і відповідально втілювати у життя свій вибір;

$\Rightarrow$ наповненість - можливість приймати себе та навколишній світ;

$\Rightarrow \quad$ відповідальність - здатність доводити до кінця рішення, ухвалені на підставі особистих цінностей;

$\Rightarrow$ свободу - спроможність людини знаходити реальні можливості для дії;

$\Rightarrow \quad$ персоналізацію - когнітивну та емоційну доступність людини до себе і до світу; самотрансценденцію - можливість людини «виходити за границі власних можливостей», перевершувати себе;

$\Rightarrow$ самодистанціювання - пошук внутрішнього вільного простору;

$\Rightarrow$ цілі в житті - наявність або відсутність цілей, які надають людини осмисленості, спрямованостій тимчасової перспективи; $\Rightarrow$ проживання життя - сприйняття людиною процесу власного життя, як цікавого, емоційно насиченого і наповненого змістом;

$\Rightarrow \quad$ життєстійкість - поєднання життєлюбства й енергійності; дієвого інтересу до життя і можливостей щодо досягнення поставлених цілей.

$\Rightarrow$ результативність життя- відображення оцінки минулого життя;

локус контроль-Я - відображає уявлення про себе як про сильну особистість, яка має свободу вибору для творення життя відповідно до своїх цілей і уявлень про його сенс. 
$\Rightarrow$ локус контроль-життя - переконання в тому, що людина може контролювати своє життя, вільно ухвалювати рішення і втілювати їх;

$\Rightarrow \quad$ контроль - розуміння людиною того, що боротьба за свої цінності дає змогу вплинути на результат;

$\Rightarrow$ ризик - впевненість людини в тому, що все те, що 3 нею трапляється, сприяє їі розвитку за рахунок усвідомлення отри- маного досвіду, -неважливо, позитивного чи негативного;

$\Rightarrow$ залучення - переконаність у тому, що життєві події є джерелом цікавого досвіду для особистості.

Експериментальне дослідження екзистенційних даностей буття особистості проведено нами у декілька етапів. У ході першого, організаційного етапу, сформовано експериментальну вибірку, що склала двадцять осіб

Таблиия 1.

\section{Ротаційна матриця компонентів}

\begin{tabular}{|c|c|c|c|c|c|c|}
\hline \multirow{3}{*}{ Шкали } & \multicolumn{3}{|c|}{ Значення } & \multicolumn{3}{|c|}{ Значення } \\
\hline & \multicolumn{3}{|c|}{ Компоненти } & \multicolumn{3}{|c|}{ Компоненти } \\
\hline & 1 & 2 & 3 & 1 & 2 & 3 \\
\hline Екзистенційність & 18,017 & 5,293 & 6,562 & ,891 & 262 & ,324 \\
\hline Сповнення & 28,471 & 11,388 & 9,968 & 882 &, 353 & ,309 \\
\hline Відповідальність & 9,989 & 2,760 & 3,526 &, 865 & ,239 &, 305 \\
\hline Свобода & 8,028 & 2,533 & 3,036 &, 852 & ,269 &, 322 \\
\hline Персоналізація & 10,455 & 6,095 & 3,407 &, 777 & 453 & 253 \\
\hline Самотрансценденція & 6,601 & 3,409 & 2,197 &, 725 & 374 & 241 \\
\hline Самодистанціювання & 3,853 & 2,686 & 1,210 & 673 & 469 & 211 \\
\hline $\begin{array}{c}\text { Загальний показник життє- } \\
\text { стійкості }\end{array}$ & 5,562 & 14,951 & 3,677 & ,336 & ,903 & ,222 \\
\hline Ціль діяльності & 2,124 & 6,836 & - & ,274 & ,881 & - \\
\hline Процес діяльності & 1,175 & 4,856 & - &, 212 &, 876 & - \\
\hline Локусконтролю-я & 1,357 & 3,224 & - & 335 &, 796 & - \\
\hline Локус контролю-життя & 1,375 & 3,443 & 1,947 & 259 &, 650 & ,367 \\
\hline Результативність діяльності & 1,333 & 2,805 & 1,893 & ,304 & 639 &, 431 \\
\hline Життєстійкість & 6,472 & - & 16,904 & ,349 & - & 9911 \\
\hline Контроль & 1,558 & - & 6,361 &, 222 & - & ,905 \\
\hline Включення & 3,344 & - & 6,967 & 411 & - &, 856 \\
\hline Тривога & - & $-3,890$ & 10,108 & - & ,289 &,- 750 \\
\hline Ризик & 1,569 &, 724 & 3,576 & 329 & 152 &, 750 \\
\hline
\end{tabular}

Кількість визначених факторів обтрунтовано нами за такими критеріями:

* $\quad$ за критерієм зрозумілості (обрано таку кількість факторів, щзодало змогу отримати найбільш зрозумілу факторну структуру);

* $\quad$ за критерісм Кайзера (виключено компоненти зі значеннями менше 1,0);

* $\quad$ за тестом «осипу» Кеттелла (встановлено, щуо найбільш значущими для подальшого аналізу є три компоненти (див. рис.1);

* $\quad$ за критерієм пояснювальної дисперсї̈ (з'ясовано, щуо саме трифактори, обумовлюють 90\% загальної накопиченої дисперсії, інші - лише незначний ї̈ процент і можуть бути відхилені (див.: табл. 2). 
різної статі, віком від 25 до 35 років, які у різний час проходили індивідуальну психотерапію. В процесі другого, підготовчого етаny, підібрано методики, що дали змогу виміряти екзистенційні даності. Під час третього, ойінного етаny, експериментальні дані було обраховано за допомогою методів математичної статистики. У ході четвертого, iнmерпретацุiйного етаny, проаналізовано визначені фактори та інтерпретовано їх змістові характеристики.

За результатами експериментального дослідження нами визначено і інтерпретовано три основних фактори, що характеризують екзистенційні даності буття особистості.

Перший фактор - «Усвідомлення са-

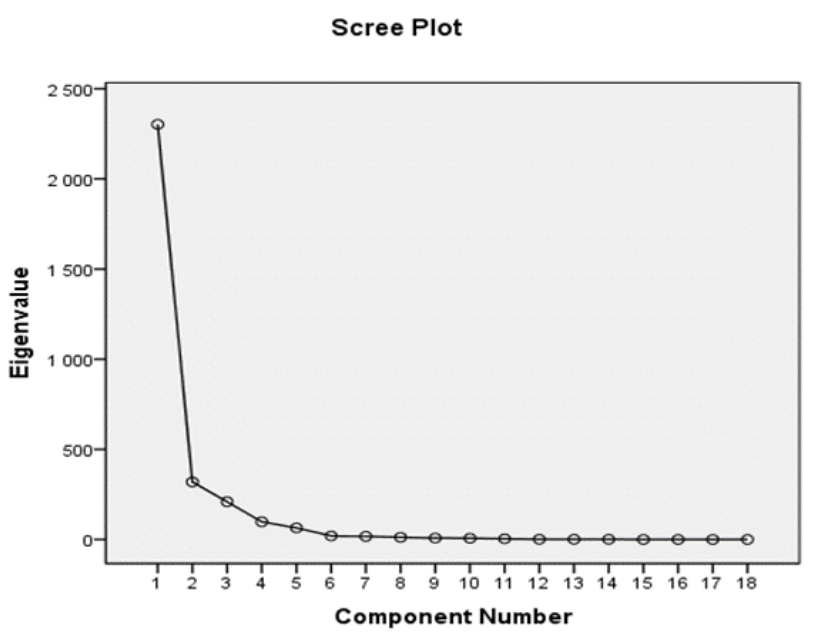

Рис. 1. Графік «осипу».

мості».

Фактор «усвідомлення самості» $є$ змістовою характеристикою, яка розкриває особистісні, сутнісні особливості, що визначають прийняття себе особистістю. Поняття, які характеризують цей фактор: самодистанціювання, самотрансценденція, свобода, відповідальність, персоналізація, екзистенційність, сповнення. Фактор визначає, яким чином людина усвідомлює власну самість. Важливими характеристиками означеного фактору є:

- $\quad$ здатність створювати власні цінності;

- самостійно ухвалювати рішення;

- $\quad$ нести відповідальність за ухвалені рішення;

- $\quad$ доступність людини до себе і до світу.

Якщо людина характеризується відсутністю вище наведених ознак, то може переживати відчуття втрати віри у власні сили.

Другий фактор - «Життєва самоперетворювальність».

Цей фактор визначає результативні та регулятивні якості особистості: «мету в житті», «загальний показник осмисленості життя», «процес життя», «результативність життя», «локус контролю-я», «локус контролюжиття». Основними характеристиками цих якостей є такі:

- $\quad$ наявність або відсутність в житті людини цілей, які надають життю осмисленості, спрямованості і перспектив щодо свого майбутнього;

- $\quad$ здатність сприймати власне життя, як цікаве, захоплююче, емоційно насичене; оцінка власного життя як позитивного, продуктивного;

уявлення про себе як про сильну особис- 
тість, яка має достатньої свободи для

вибору, здатна відтворювати своє життя лювати своє життя;

задоволення від власної діяльності / від-

Таблиия 2.

\section{Загальна пояснювальна дисперсія}

\begin{tabular}{|c|c|c|c|c|c|c|c|c|c|}
\hline \multirow[b]{2}{*}{ 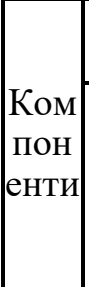 } & \multicolumn{3}{|c|}{$\begin{array}{c}\text { Початкові власні значення } \\
\text { компонентів } \\
\end{array}$} & \multicolumn{3}{|c|}{$\begin{array}{c}\text { Екстракційні суми квадратних } \\
\text { навантажень } \\
\end{array}$} & \multicolumn{3}{|c|}{$\begin{array}{c}\text { Суми квадратних навантажень піс- } \\
\text { ля ротації } \\
\end{array}$} \\
\hline & Загалом & $\begin{array}{c}\text { Про- } \\
\text { цент } \\
\text { диспе- } \\
\text { рсії }\end{array}$ & $\begin{array}{c}\text { Куму- } \\
\text { лятивн } \\
\text { ийпро } \\
\text { цент }\end{array}$ & $\begin{array}{c}\text { Зага- } \\
\text { лом }\end{array}$ & $\begin{array}{l}\text { Процент } \\
\text { дисперсії }\end{array}$ & $\begin{array}{c}\text { Кумуля- } \\
\text { тиний } \\
\text { процент }\end{array}$ & Загалом & $\begin{array}{c}\text { Процент } \\
\text { диспер- } \\
\text { сії }\end{array}$ & $\begin{array}{c}\text { Кумуля- } \\
\text { тивний } \\
\text { процент }\end{array}$ \\
\hline 1 & 2302,545 & 75,179 & 75,179 & 2302,545 & 75,179 & 75,179 & 1580,945 & 51,619 & 51,619 \\
\hline 2 & 319,092 & 10,419 & 85,598 & 319,092 & 10,419 & 98 & 530,477 & 17,320 & 68,939 \\
\hline 3 & 209,322 & 6,834 & 92,432 & 209,322 & 6,834 & 92,432 & 652,175 & 21,294 & 90,233 \\
\hline
\end{tabular}

відповідно до своїх цілей і уявлень про сенс існування;

- $\quad$ впевненість у власній здатності контролювати життя, вільно схвалювати рішення та втілювати їх;

- $\quad$ відчуття впевненості щодо власного минулого та майбутнього.

Якщо вищенаведені аспекти не реалізовуються, людина відчуває свою слабкість, не розуміє, що саме керує нею, не має певних цілей, вважає життя нецікавім, буденним.

Третій фактор - «Самоактивація життєстійкості».

Фактор розкриває такі сутнісні якості особистості: життєстійкість, контроль, залучення, прийняття ризику, тривога. Причому, показник тривоги впливає на прийняття ризику та контролю, визначає, яким чином людина активує власну життєстійкість. Для такої активізації необхідні:

- низький рівень тривоги, що визначає здатність людини ризикувати та контро- чуття екзистенційного вакууму;

- вплив вольового зусилля на результат діяльності / безвольність;

- надмірний контроль над результатом власної діяльності / відчуття своєї безпорадності (ілюзія контролю);

- $\quad$ набуття особистістю позитивного чи негативного досвіду (прийняття ризику) / прагнення до комфорту i безпеки (уникнення небезпеки).

Фактор «Самоактивації життєстійкості», таким чином, розкриває регулятивні характеристики поведінки особистості.

\section{Висновки і перспективи подальших}

досліджень. Отже, в ході експериментального дослідження нами було визначено три фактори, які розкривають екзистенційні даності буття особистості, а саме: «усвідомлення самості», «життєва самоперетворювальність», «самоактивація життєстійкості». Вважаємо, що ці фактори в цілому визначають екзистенційну ситуацію особистості і дають змогу роз- 
робити ефективну стратегію практичної роботи 3 клієнтом. Створення моделі конструктивного, осмисленого життя людини - багатомірний процес.

На наш погляд, подальші дослідження щодо вивчення особливостей екзистенційних даностей буття як механізмів регуляції поведінки особистості є вельми перспективним дослідницьким напрямком.

\section{Перелік використаних джерел:}

1. Райгородский Д. Л. Практическая психодиагностика. Методики и тесты: учебноепособие- К. : Самара, 1998. $-672 \mathrm{c}$.

2. Лэнгле А. Эмоции и экзистенция: учебноепособие М .: Гуманитарный центр, 2011. - 284 с.

3. Осин E. Н. Краткая версия теста жизнестойкости: психометрические характеристики и применение в организационном контексте: Вестник Московского университета. - Серия №14. Психология. / Осин Е.Н., Рассказова Е.И. - К. : 2013. - С.147-165.

4. Ялом И. Экзистенциальная психотерапия. - М. : Класс, 1999. - 608 с.

5. Василюк Ф. Е. Психология переживания: моногр. М. : Изд-во Моск. ун-та, 1984. - 200 с.

6. Мадди С. Теорииличности: сравнительный анализ. М. : Речь, 2002. -539 с.

7. Лэнг Р. Д. Расколотое Я. - СПб.: Белый кролик, 1995. $-352 \mathrm{c}$.

8. Кюблер-Росс Э. О смерти и умирании. Пер. с анг. К. : София, 2001. - 320 с.

9. Кочюнас $P$. Контуры экзистенциальной терапии. Экзистенциальная традиция: философия, психология, психотерапия: учебное пособие. - М. : Учебный центр, 2007. $-134 \mathrm{c}$.

10. Тиллих П. Систематическая теология. - Т. 1-2 (Перевод с англ. Т.П. Лифинцевой). - М., СПб., 2000. -
$412 \mathrm{c}$.

11. Баскаков В. Ю. Танатотерапия. Теоретические основы и практическое применение: учебное пособие. М. : Институт общегуманитарных исследований, 2007. $-184 \mathrm{c}$.

\section{References (Transliteration):}

1. Raygorodskiy D. L. Prakticheskaya psihodiagnostika. Metodiki i testyi: uchebnoeposobie- K. : Samara, 1998. $672 \mathrm{~s}$.

2. Lengle A. Emotsii i ekzistentsiya: uchebnoeposobie M .: Gumanitarnyiy tsentr, 2011. - $284 \mathrm{~s}$.

3. Osin E. N. Kratkaya versiya testa zhiznestoykosti: psihometricheskie harakteristiki i primenenie $\mathrm{v}$ organizatsionnom kontekste: Vestnik Moskovskogo universiteta. - Seriya \#14. Psihologiya. / Osin E.N., Rasskazova E.I. - K. : 2013. - S.147-165.

4. Yalom I. Ekzistentsialnaya psihoterapiya. - M. : Klass, 1999. $-608 \mathrm{~s}$.

5. Vasilyuk F. E. Psihologiya perezhivaniya: monogr. - M. : Izd-vo Mosk. un-ta, 1984. - $200 \mathrm{~s}$.

6. Maddi S. Teoriilichnosti: sravnitelnyiy analiz. - M. : Rech, 2002. -539 s.

7. Leng R. D. Raskolotoe Ya. - SPb.: Belyiy krolik, 1995.$352 \mathrm{~s}$.

8. Kyubler-Ross E. O smerti i umiranii. Per. s ang. - K. : Sofiya, 2001. $-320 \mathrm{~s}$.

9. Kochyunas $R$. Konturyi ekzistentsialnoy terapii. Ekzistentsialnaya traditsiya: filosofiya, psihologiya, psihoterapiya: uchebnoe posobie. - M. : Uchebnyiy tsentr, 2007. $134 \mathrm{~s}$.

10. Tillih P. Sistematicheskaya teologiya. - T. 1-2 (Perevod s angl. T.P. Lifintsevoy). - M., SPb., 2000. - 412 s.

11. Baskakov V. Yu. Tanatoterapiya. Teoreticheskie osnovyi i prakticheskoe primenenie: uchebnoe posobie. - M. : Institut obschegumanitarnyih issledovaniy, 2007. - $184 \mathrm{~s}$. 


\section{Panfilov Dmitriy}

PhD student of the laboratory of psychology of communication, Institute of Social and Political Psychology of the National Academy of Educational Sciences of Ukraine, Kyiv (Ukraine)

\section{THE EXPERIMENTAL STUDY OF THE EXISTENTIAL GIVENS OF PERSONAL EXISTENCE}

\section{ABSTRACT}

The article is dedicated to the experimental study of the existential givens of personal existence by using existential research methods. Existential psychology focuses on range of the givens of existence, such as death, isolation, freedom, absurdity, the courage to be, responsibility for one's life, resilience and others. Each existential given is attended by the personal feeling of existential anxiety. Confrontation with these givens results in a so-called existential conflict. Irvin Yalom points out three personal existential conflicts: between the need to live and the inevitability of death, between existential isolation and the desire for symbiosis, and between freedom and necessity.

In order to achieve our goal in the process of studying the existential identities of the person being, we used the following methods: Shihan's scale of anxiety, the scale of existential, S. Muddy's viability test, the test of semiotic orientations (LSH).

Our methods allow us to investigate: existential, fullness, responsibility, freedom, personalization, self-transcendence, self-denial, goals in life, living in life, survival, life-performance, lo- cus of control-I, locus of control-life, control, risk and involvement in life.

Experimental study of the existential givens of personality has been carried out by us in several stages. During the first, organizational phase, an experimental sample of twenty people of different sex, aged 25 to 35 years old, who at different times passed individual psychotherapy, was formed. In the process of the second, preparatory stage, methods have been selected that made it possible to measure existential data. During the third, estimated stage, the experimental data were calculated using mathematical statistics methods. During the fourth, the interpretation stage, the identified factors are analyzed and their content characteristics are interpreted.

The number of factors we determined was based on the following criteria:

$\Rightarrow \quad$ on the criterion of comprehensiveness (the number of factors was chosen, which made it possible to obtain the most understandable factor structure);

$\Rightarrow \quad$ by the Kaiser criterion (components with values less than 1.0 are excluded);

$\Rightarrow \quad$ according to the Kettle test "oscillation" (it is found that three components are the most significant for further analysis);

$\Rightarrow \quad$ by the criterion of the explanatory dispersion (it was found that the three factors determine $90 \%$ of the total accumulated dispersion, while others are only insignificant and can be rejected.

As the result of the experimental study, 
we defined and interpreted three major factors that characterize the givens of personal existence. The first factor - "awareness of self" - is a content characteristic that reveals personal, essential characteristics that identify self-acceptance of a person. Concepts that characterize this factor are self-distancing, self-transcendence, freedom, responsibility, personalization, existentiality, fulfillment. The second factor - "vital selfconvertibility" - identifies productive and regulative qualities of a person, such as "purpose of life", "general indicator of meaningfulness of life", "process of life", "life performance", "locus of control-self", "locus of control-life". The third factor - "self-activation of resilience" - unveils such essential personal qualities as resilience, control, involvement, risk-taking, anxiety.

Above-mentioned factors generally define the existential situation of a person and allow to develop an effective strategy of practical work with a client. In our view, further study of the specific aspects of existential givens as mechanisms of personal behaviour regulation is a greatly promising research direction.

Key words: existence, existential givens, resilience, self, awareness of self, vital selfconvertibility, self-activation.

\section{Панфилов Дмитрий Анатольевич}

Аспирант лаборатории психологии общения, Институт сочиальной и политической психологии Национальной академии педагогических наук Украины, г. Киев (Украина)

\section{ЭКСПЕРИМЕНТАЛЬНОЕ ИЗУЧЕНИЕ ЭКЗИСТЕНЦИАЛЬНЫХ ДАННОСТЕЙ БЫТИЯ ЛИЧНОСТИ}

Аннотация. В статье представлены результаты экспериментального исследования экзистенциальных данностей бытия личности. Для достижения поставленной цели в процессе исследования экзистенциальных данностей бытия личности нами использованы следующие методики: шкала тревоги Шихана, шкала экзистенции, тест жизнестойкости С. Мадди, тест смысложизненных ориентаций (СЖО).

Избранные нами методики позволяют исследовать: екзистенциальность, наполненность, ответственность, свободу, персонализацию, самотрансценденции, самодистанцирования, цели в жизни, проживания жизни, жизнестойкость, результативность жизни, локус контроля-Я, локус контроля-жизнь, контроль, риск и привлечения в жизнь.

Экспериментальное исследование экзистенциальных данностей бытия личности проведено нами в несколько этапов. В ходе первого, организационного этапа, сформирован экспериментальную выборку, составила двадцать человек разного пола в возрасте от 25 до 35 лет, в разное время проходили индивидуальную психотерапию. В процессе второго, подготовительного этапа, подобрано мето- 
дики, которые позволили измерить экзистенциальные данности. Во время третьего, оценочного этапа, экспериментальные данные были рассчитан с помощью методов математической статистики. В ходе четвертого, интерпретационного этапа, проанализированы определенные факторы и интерпретировано их содержательные характеристики.

Количество определенных факторов обоснованно нами по следующим критериям: $\Rightarrow \quad$ по критерию ясности (избран такое количество факторов, что позволило получить наиболее понятную факторную структуру);

$\Rightarrow \quad$ по критерию Кайзера (исключено компоненты со значениями меньше 1,0);

$\Rightarrow$ по тесту «осыпи» Кеттелла (установлено, что наиболее значимыми для дальнейшего анализа есть три компоненты);

$\Rightarrow \quad$ по критерию пояснительной дисперсии (выяснено, что именно три фактора, обусловливающих 90\% общей накопленной дисперсии, другие - лишь незначительный ее процент и могут быть отклонены.

На основании полученных данных выделены три фактора, которые определяют экзистенциальную ситуацию личности. Фактор «осознание самости» является содержательной характеристикой, раскрывает личностные, сущностные особенности, определяющие при- нятие себя личностью. «Жизненная самопревращаемость» - этот фактор определяет результативные и регулятивные качества личности: «цель в жизни», «общий показатель осмысленности жизни», «процесс жизни», «результативность жизни», «локус контроляя», «локус контроля-жизнь». «Самоактивация жизнестойкости» - раскрывает такие сущностные качества личности: жизнестойкость, контроль, привлечение, принятие риска, тревога.

Выше указанные факторы в целом определяют экзистенциальную ситуацию личности и позволяют разработать эффективную стратегию практической работы с клиентом, в том числе в русле психологического консультирования и психотерапии. Создание модели конструктивного, осмысленной жизни человека - многомерный процесс.

Ключевые слова: экзистенциальные данности бытия, личность, экзистенция, жизнестокойсть, самость, жизненная самопревращаемость, самоактивация.

Дата отримання статті: 15.02 .2018

Дата рекомендації до друку: 28.02.2018 